\title{
Smithsonian to study museums' role after dropping A-bomb exhibition
}

Washington. Michael Heyman, the secretary of the Smithsonian Institution in Washington, announced on Monday that the institution is to mount a joint forum with the University of Michigan to look at how museums handle controversial topics - and in particular at the role of the Smithsonian as a national museum.

The announcement coincided with a decision by the Board of Regents of the Smithsonian, after a year-long battle between war veterans and the museum, to cancel an exhibition devised as a vehicle to display the Enola Gay - the plane that dropped an atomic bomb on Hiroshima on 6 August 1945.

In place of the planned exhibit, which had provoked fierce protest over conflicting interpretations of the historical significance of the event, only the plane and a video about its crew will now be shown. The Smithsonian says it is considering a series of symposia tackling the historical issues surrounding the Enola Gay at a later date.

Presenting the board's decision, which was reached unanimously, Heyman said he felt that it had made a "basic error" in trying to link together an historical treatment of the use of atomic weapons with an exhibition designed to commemorate the end of the Second World War.

The board, of which Heyman is secretary, includes members of both the public and of Congress. It had come under pressure from many sides. Last month, for example, 81 members from both sides of the House had called for the resignation of Martin Harwit, director of the National Air and Space Museum, which is responsible for displaying the Enola Gay. The board did not back the call.

Previously, veterans' groups had called through organizations such as the American Legion for the cancellation of the exhibit, despite expressing a desire to see the plane on display. But the Organization of American Historians wrote to William Renquist, the board's chairman and US Chief Justice, claiming that cancelling the exhibit would set a dangerous precedent of censorship under pressure from special interest groups.

Speaking after the meeting, Senator Dan- iel Patrick Moynihan(Democrat, New York), a board member, emphasized that it had been unanimously decided to replace the exhibition with something less judgmental.

Although the board has now made its views known on the proposed Enola Gay exhibit, the issues raised by the controversy over its portrayal of one of the defining events of the twentieth century is set to continue. Such issues include questions about the use of history in American politics and the extent to which ideology can colour a

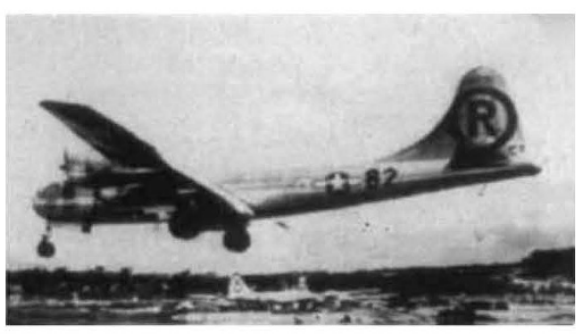

scientists who have complained that it emphasizes the negative consequences of science on society, and underestimates the pusitive contribution.

In an article due to appear in Science Communication, published by the American Association for the Advancement of Science (AAAS), Marcel LaFollette, an associate professor at George Washington University, expresses concern at the way retrospective moralizing appears to be creeping into some exhibits.

The Enola Gay has been in the Smithsonian collection since 1949. Restoration began 11 years ago, and will have eventually cost the museum $\$ 1$ million. The complete aircraft will go on permanent

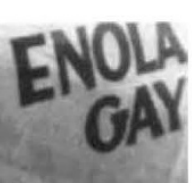

museum exhibit.

Other issues range from the difference between memory and history to the role of a national museum versus one that is privately funded, and the role which the curator of a museum plays when displaying artifacts - as opposed to that of a scholar publishing

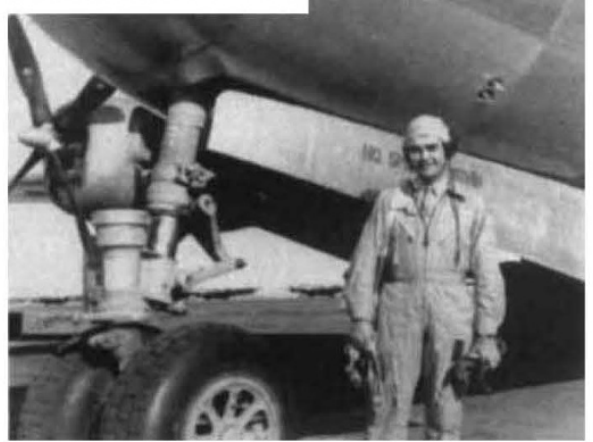

The Enola Gay (top) returns from its mission. Its pilot Paul Tibbets (above) has joined critics of the proposed display. display at the National Air and Space Museum's new site, currently being developed at Dulles International Airport outside the national capital.

Meanwhile the museum has already moved the forward fuselage of the plane into the museum where it sits shrouded, awaiting an unveiling in May. (The weight of the complete plane exceeds the museum's load-bearing design specifications).

Prior to this work under his or her own name.

The controversy, which has included charges that personal ideology plays an excessive role in some curatorial decisions, has already led to the postponement of an exhibit about Vietnam. It has also contributed to Heyman's decision to appoint an independent panel to evaluate another controversial exhibit Science in American Life.

The latter exhibit, mounted by the National Museum of American History another of the Smithsonian's complex of museums - has come under fire from many

\section{NIH selects new alternative medicine head}

Washington. Wayne Jonas, the director of the Medical Research Fellowship at the Walter Reed Army Institute of Research in Washington D. C., is to be the new head of the Office of Alternative Medicine at the US National Institutes of Health. Jonas, who takes up his post in July, has worked in immunology and toxicology, and has a background in homeopathy.

Marc Micozzi, director of the National Museum of Health and Medicine, says that Jonas will be "excellent" in the post. Micozzi is also editor in chief of the Journal of Alternative and Complementary Medicine, a peer-reviewed journal which publishes its first issue this week. week's cancellation, the exhibit had passed through a number of incarnations, originating several years ago with the idea of examining the events surrounding the dropping of the atomic bomb in the context of the start of the Cold War.

But some observers say that Harwit was equally keen to see an exhibit placing the plane in the context of the end of the Second World War. The decision to create two foci for the exhibit seems to have caused much of the subsequent trouble - but not all.

Early scripts contained a sentence saying that for most Americans it was a "war of vengeance", whereas "for most Japanese, it was a war to defend their unique culture against Western Imperialism." Whatever was intended by those words, veterans' groups have interpreted them to mean that they are racist avengers.

Much of the subsequent rhetoric has focused on the casualty estimates for an invasion of the mainland that military advisers gave to President Harry Truman.

Helen Gavaghan 